\title{
ECHOES FROM THE GREAT DIVIDE: ON THE FALTERING PHILOSOPHICAL DIALOGUE BETWEEN AFRICA AND THE WEST
}

\author{
PETER ABSPOEL
}

\begin{abstract}
Even in the field of comparative or cross-cultural philosophy, distinctive contributions by African philosophers are often side-lined - that is, relegated to niche publications. Why is it so hard for African philosophers to draw their Western colleagues (other than specialists in African philosophy) into a real dialogue? An attempt is made to describe the field of tension; it is shown that some of the reflexes that manifest themselves in it reveal not just the attachment to specific perspectives or frames of reference, but also implicit ideas about the nature of the "philosophical game". On the Western side, motives constitutive of practical or traditional life are either ignored or tacitly equated with attempts to realize goals that can be best understood from a reflexive point of view. In this way, the concrete conditions of any human activity, including intellectual activity, are lost from view. This critical lesson has been spelt out by a number of philosophers (Maurice Blondel being one of them), but is seldom taken to heart. As a result, it becomes difficult to penetrate beyond conceptual differences. It will also be maintained that while many African philosophers question intellectualist attitudes, they do not always do so in a way that invites discussion on the central, or basic, issues.
\end{abstract}

Keywords: African philosophy, comparative philosophy, cross-cultural philosophy, intellectualism, Maurice Blondel, practice

Yet words are thieves that lull the watchman

- Mazisi Kunene

\section{INTRODUCTION}

Many African cultural products are widely appreciated in the West. Music travels most easily; but there is also a flourishing market for African novels, films and works of art. In fact, modern African literature finds a wider audience in the West than in Africa itself. Distinctive contributions of Africans to philosophy are less lucky (not counting

ABSPOEL, PETER: PhD. in Philosophy, Independent Scholar, the Netherlands. Email: abspoel@online.nl 
some popular tracts on ubuntu). It isn't just that fewer people are interested in philosophy than in music or literature. Proponents of African philosophy have a hard time getting the attention of their Western colleagues, and drawing them into a real exchange of views. Why is this so?

Here I will present my own view on the matter in broad strokes. My excuse for employing this rather coarse technique is that I aim to offer a fresh perspective which may further discussion. Over the years, I have explored the gap between the African and Western intellectual worlds in different ways, as a cultural anthropologist and a philosopher of culture. I am also familiar with literary circles which offer a contrasting example: here differences of perspective are welcomed and seen as a source of enrichment.

First, I would like to draw attention to the paradoxical nature of the indicated state of affairs. The paradox can be stated in the following way. Philosophers attempt to rise in thought to general principles structuring life. And in many cases they believe concrete life is structured to a high degree by conceptual schemes, tied to language, that differ from one culture to another. Now, following their logic, one would expect that a maximum of meaningful interaction between cultures would be realized among philosophers, who share a technical language capable of bringing out both contrasts and similarities. But the facts seem to belie this thesis (at least as far as relations between Africa and the West are concerned). Should we assume a lack of interest, or bland ethnocentrism, on the side of Westerners, as some African philosophers, like Jonathan Chimakonam (2018a), do? But why would philosophers differ in this regard from other Westerners? It would be important to see if the philosophical perspective itself (in its customary forms) hides from view potential points of contact that nonphilosophers manage to find more easily. Why would novels, that are also composed of words, travel almost effortlessly through the membranes separating cultural worlds, while philosophical views tend to get stuck?

Here I will try to shed some light on factors hampering the philosophical dialogue that are hardly ever discussed by the participants themselves. This requires adopting a wide perspective, which allows us to situate the discussion (not just the views) in the context of culture patterns, while also taking into consideration the particularities of the "philosophical game".

It is hoped that a better understanding of the issues at stake will allow the dialogue to move forward and engage more participants. By no means do I intend to downplay the amount of productive interaction already taking place between committed philosophers. However, these "good examples" often (have to) place themselves outside of the mainstream of current philosophical debates. Or rather, they have to struggle against a current powered by an, often implicit, "paradigm" of universalism and anti-traditionalism, which tends to obscure the philosophical relevance of ideas betraying a greater respect for common sense and for the life which nurtures it. But I will also maintain that African philosophers sometimes expound their views in a way that makes them unnecessarily difficult for Westerners to digest. 


\section{ON THE APPROACH}

In order to get to the bottom of the issue, I think it is necessary to thematize the relation between philosophical knowledge and the kind of knowing that people rely on in practice, or ordinary life.

Western philosophy thrives on diversity, that is, on comparing different views. At the same time it reduces this diversity by limiting itself to views that can be discussed in abstraction from life. Major strands of African philosophy seem to question this procedure and its normative assumptions; but they often do so implicitly. Therefore they risk being seen as "too different" by Westerners. If an attempt is made to connect thought to practice, this is often done by employing the terms of hermeneuticians, Wittgensteinians, and sometimes post-structuralists. This involves the risk of subscribing to a semantic-ontological relativism that is in fact a shadow of the Western contempt for tradition that African philosophy set out to challenge. Meanwhile, posing as "the other" (in Western eyes) can stand in the way of a critical discussion on reified cultural identities and views. Internal differences between points of view - such as those between men and women - may be smoothed over by insisting Africans are "communalists", for example.

In comparative philosophy, different strategies have been devised to drive out the specter of "radical incommensurability", with its attendants of conceptual and moral relativity - invoked by Richard Rorty (1989), among others. Some posit similarities that can be integrated in a universalistic model (like Martha Nussbaum, 1993); some suggest that by learning about the other tradition we can get accustomed to a world of different meanings and values (David Wong, 1989, for example); others believe in the possibility of a Gadamerian "merging of horizons" which brings a cognitive gain; here we can think of Alasdair MacIntyre (1990, 1991), who combines a hermeneutic view of tradition with an Aristotelian view of the virtues. Donald Davidson $(1980,1982)$ and Michele Moody-Adams (1997) also point a way out of incommensurability through interpretation. Often it is supposed that language and conceptual schemes are constitutive of life-worlds and human experience. This (very common) assumption deserves to be questioned - at least in its more categorical forms. The problem of translatability may come to haunt comparative philosophy to a point where differences in attitudes to life or ways of thinking either seem absolute, or seem insignificant, depending on the function one assigns to language.

As Richard Bernstein (1991) has suggested: the very idea of incommensurability may be the product of a desire to reduce "the other" to the same which dominates the Western philosophical mind; and the desire to rehabilitate the other as the completely different, as undertaken by Emmanuel Levinas, may be seen as its mirror image. Now, we can say that, in Western philosophy, the other that is either ignored, prematurely assimilated or appearing as an opaque anomaly also presents itself in the form of 
practical life. But this "other" we need to be (or become) ourselves, and therefore it cannot be totally alien or devoid of philosophical significance.

Valuable resources for gaining insight in the relation between reflexive thought and unreflected experience can be found in the works of Maurice Blondel, Michael Polanyi, Pierre Bourdieu, and Bruno Latour. Their views cannot easily be amalgamated, however. Let me try to state in a few words what important lessons we can learn from these authors. I shall also point to what I consider to be the limitations of their views.

(1) Bourdieu (1980) warns that we tend to misconstrue the kind of motives that human beings rely on in practical life if we want to explain them on the basis of explicit (e.g., religious or ontological) views. There is a logic of practice, encapsulated by the habitus, which can only be understood in relation to life as experienced in concrete situations, and in time. Thus, he says, anthropologists are wrong if they believe the behavior of people is guided by the synoptic views of cultural worlds (often exegesed as a coherent text, full of symbolic harmonies and contrasts) they capture in their monographs. In fact, if they do so, they make a double mistake; they confuse views with motives, and they confuse the views they construe as observers with those held by the people they study (51 ff.). This criticism, I would say, applies to philosophers as well, especially to those who focus on the view of life given with or in language, myths, etc. (Many African philosophers, as we shall see, also seem to think that cultural views determine the practical attitude to life of groups.) However, I would say Bourdieu's concept of the habitus (see e.g. 1980, Ch. 3 and 4) is itself tainted by a reductionist logic. This is not too apparent, as he stresses the interdependence of concrete and semiotic determinants of action. But the latter predominate - even though they are not seen as the product of conscious reflection. The habitus is supposed to generate thoughts, feelings and actions on the basis of elementary oppositions, which are internalized so deeply that they seem indistinguishable from the body. Another problem with Bourdieu's model is that it is so general that it makes it difficult to focus on the differences between cultures. Everywhere, people are disposed to make the most of their "symbolic capital", trying to convert it into power; but this capital consists of arbitrary ideas, distinctions, expressions of taste, etc. (see Bourdieu and Passeron 1970; Bourdieu 1979). Although Bourdieu wants us to realize that we are prone to mistake arbitrary distinctions for natural ones, and thereby (often unwittingly) help to reproduce existing power relations, it isn't clear at all what resources remain for giving meaning to life once we have shed our blinkers.

(2) Latour, on the other hand, has a great deal to say about cultural differences, especially those between the modern West and "premodern" societies. The Western feeling of superiority, he claims, is tied to the idea that modern science and philosophy have allowed a process of intellectual "purification", leading to the establishment of a clear-cut distinction between the objective and subjective, the natural and the social, the non-human and the human (1993, 10 ff., 29 ff.). Modern Westerners take pride in the fact that they have distanced themselves from a premodern mentality, which mixes up meanings and facts. Thinking of nature in deterministic terms, they can feel liberated from traditional constraints, and free to engage in social experiments. They also feel they are in possession of a universal yardstick by which they can measure the "others" 
- or their cultures. But according to Latour, the Western, modern self-image is largely a deliberately entertained fiction ( $39 \mathrm{ff}$.). The Great Divide, imagined to separate the West from the rest of the world, is in fact a projection of an internal divide, which cuts across the lives of all, including scientists (97-99). The objects science deals with are "quasi-objects", "hybrids" composed of objective and subjective elements; the scientists are embedded in networks of action that mediate between the human and the extra-human in a way that is not accounted for in their epistemologies. What distinguishes Western society, is the scope and diversity of these networks (117). A host of "quasi-objects" is produced, along with a host of different kinds of subjects. But the whole is still a social construction, including the action of focusing on the objective properties of natural things. Westerners, therefore, should realize they are not really different from those they think they are separated from by the Great Divide (103). The networks in which they are at home, are "simultaneously real, like nature, narrated, like discourse, and collective, like society" (6). He also stresses that these networks, while being constructions, always have to accommodate a host of given human concerns. In every society, people accept the reality of very different things, which come with their own discourses: nature, technology, ethics, love, religion, art, etc. Though Latour offers a cogent criticism of views that reduce everything to physics or to language, I feel he too easily resigns himself to the incommensurability of different human motives or "modes of reality" (see Latour 2012). It is enough, he seems to think, if we do not let our quest for objective knowledge repress our other spontaneous interests. In this way, he thinks, we can realize the ideals pursued by Enlightenment thinkers, which have been lost from view since the human sciences tried to "purify" the view of man as well as that of nature $(1993,35-36,142)$. Thus, in the end, one wonders if doing justice to the inner divide (in his view) really amounts to the same thing as breaking down the Great Divide.

(3) Polanyi, like Latour, points out that scientific knowledge is not something sui generis. He focuses on the epistemic foundations of knowledge, not only stressing the importance of social conditions, but also the fact that it is impossible to structure knowledge on the basis of facts and logic alone. Every kind of explicit knowledge, that we can express in words or mathematical symbols, requires tacit knowledge to become thinkable. If we attend to things we want to know, we always attend to them from something else, which remains unsaid, and always at least partly unsayable $(1966,10)$. For example, if we want to study a frog in laboratory, we still need tacit knowing to be able to trap and manipulate one - and even to know what kind of animal we are looking for (20-21). Science requires specific skills which, like any skills, can only be acquired by imitating others in practice. Many unspoken rules must be internalized tacitly, before we are able to intelligently commit ourselves to scientific activities (29 ff.). We can only grasp and apply "articulate frameworks" if we come to inhabit them like our body, or if they come to "dwell" in us $(1956,208 ; 1966,17)$. By using these metaphors, Polanyi wants to emphasize that, though a conception of reality may direct our thinking and actions, it doesn't limit us in the way explicit assumptions do: it rather stimulates our creativity and reminds us that there is always more to know. He judges the value of (internalized) conceptions of reality by their productive capacity; and to him, modern 
science, because of its proven ability to discover and explore new realms of reality, and to describe their structure, is clearly superior to traditional ways of thinking (e.g., 1956, 224-226). Somewhat like Latour, he criticizes scientists not for what they do, but only for not properly understanding what they are doing - that is, for not acknowledging their dependence on conditions they cannot grasp in scientific terms. To him, ultimately, tacit knowing is a condition for acquiring knowledge in a methodical way. At some point, he believes, our typically human, word- or concept-dependent knowledge takes over, allowing us to recognize intelligible patterns not immediate given in our sense-dependent experience, and to test hypotheses (1966, $70 \mathrm{ff}$.). We always need intuitive thinking to invent, understand or criticize theories; but scientific (or philosophical) thinking, though participating in the spontaneous processes responsible for tacit knowing, is reasonable in a way that our immediate experience is not.

(4) Blondel (though the first-born of the philosophers mentioned) goes further. Like Polanyi, he maintains that we always need to combine some form of direct knowing (connaissance directe, pensée réelle) with discursive thought (e.g. 1934b, 21 ff.). But unlike Polanyi, he doesn't see practical knowledge as just a condition for theory. Neither form of knowledge supplies the building blocks which allow us to construct a closed world, intelligible in itself; and we cannot merge both cognitive perspectives, creating one picture of reality. Practice and theory, he says, do not "duplicate each other's efforts" (1906a, 561); we need them both, and we need something transcending them both, and mediating between them, in order to enable them to enrich each other. Therefore, we never live in a world of facts, objects, or ideas, able to be stabilized in or by thought. Our conscience can never exhaust what we experience, and neither what we think (e.g., 1934a, 221). Even if there is a richness in experience which is reflected in irreducible or incommensurable kinds of knowledge, Blondel doesn't believe - as Latour seems to do - that we can resign ourselves to a life consisting in a succession of experiences which are meaningful in completely different ways. All we experience and think about is relevant for us, he claims, because we believe it can bring us further; or, to put it differently, because we think it can help us to become more ourselves. Disparate experiences must have something to do with each other; for if we hadn't been able to integrate them, at least in a provisional way, we couldn't have become what we are. This means that there is no ready-made recipe for realizing ourselves (further). We are faced with a "problem of action" (or "problem of life"; see e.g., 1893, 24, 28) which cannot be reduced to an intellectual problem: we want to find out what we can become by responding to very diverse stimuli (internal and external) inciting us to look for a life that is richer or more promising than anything we can realize relying on our active powers and our ideas. We fall into the trap of intellectualism if we think we should, or even could, tailor our expectations to a reflexive inventorization of what life has to offer (see e.g., 1934a, 163-164).

Blondel's view of the relation between praxis and theory makes him assign an indispensable role to tradition. Without being initiated into a concrete, traditional way of life, he says, we would never become aware of "the problem of life"; and we need the provisional answers that traditions supply us with (not just views and ideas, but also 
ways of acting) to have any idea of what we want to become (see e.g., 1893, xiii, 427 ff.; 1898, 213). Tradition doesn't just provide a group with specific views or ideas; it is also a life which enables a "fertile contact" between people (1976, 1140-1141); and this means that the "philosophy" people actually live by can never completely be explicated. It belongs to the task of an "integral philosophy", according to Blondel, to point this out (e.g., 1936, 232; 1937, 319 ff,). Blondel's philosophy offers many important clues, I believe, for African philosophers thinking about the meaning of tradition, and also for diagnosing the (excessive) intellectualism that closes the Western philosophical perspective to any kind of "traditional wisdom". It also seems to align well with the metaphysical preoccupations expressed in many African views of reality. However, Blondel entertains some notions which I find questionable, like the idea that human beings are driven by a desire to make everything they feel to be meaningful a possession, and also the idea that every form of transcendence found in life must somehow correspond, in a way we cannot fathom, to the absolute (see Abspoel 2018).

One important point on which these thinkers agree, is worth noticing: the sphere of practical life has a (relative) autonomy in relation to "reflected life"; therefore we should resist the temptation to reduce the dynamism of life to thinkable motives. Much of Western philosophy suffers from defects stemming from intellectualism; and many African philosophers, either as a result of their formation, or because they want to be taken seriously by Western philosophers, also tend to overstate the human dependence on explicit views and language.

Reflexive constructions are often the center of attention. Take this rather typical statement by Kwame Gyekye (he builds here on the views of Alexis Kagame and John Mbiti, and doesn't seem to be aware of echoing Johann Gottfried Herder): “...language does not merely suggest, but may also embody, philosophical perspectives. For it seems that every language implies or suggests a vision of the world" $(1995,31)$.

Once this principle is accepted, it seems logical to try to elucidate a specific "vision of the world" by studying constructions made of words. The limitations of this approach can be illustrated by looking at the article "An Outline of a Theory of Destiny" by Segun Gbadegesin (2004). The conception of destiny the Yoruba believe in is delineated by presenting myths, which describe how every human being chooses his or her destiny before being born. In the way typical of the analytical philosophical tradition (which has influenced many English-speaking African philosophers) Gbadegesin distils from the myths a number of propositions in order to assess their logical compatibility. The living human being is supposed to be composed of different parts, some of which are "added" after the acceptance of a destiny, or after birth, which raises the problem whether there is, in the circumstances described by the myth, any complete person able to choose. After stating the logical problems involved in the "traditional view", the author points out that in real life people do not seem to be hindered by them, and that, moreover, they do not seem to accept the implications of the view they hold. They "act as if they believe that destiny is alterable" (65). Now, from a Blondellian perspective, this would be begging the question whether we can say that the view expressed in the myths is really the "philosophy" people live by, and this should prompt us to look for signs that show that the mythical propositions are 
somehow balanced against others, within a more comprehensive view of life. Why would we choose to take Plato's "Myth of Er" (found at the end of The Republic), which states a very similar view, not literally, and not pick it apart in the same way? Are the Yoruba, unlike Plato, unable to distinguish between the mythopoetic and the real? Why couldn't people be impressed by the fact that persons are different, and seem to be "destined" for a certain life, while maintaining that they are responsible for what they turn into, and for the way they use their talents? The fact that therapeutic rituals exist which aim to change a person's "chosen" destiny (hinted at by Gbadegesin on page 65), doesn't answer the question how much of the myth is taken literally especially outside of the ritual context.

On the other hand, it will not do to deny to conceptual schemes any relation to reality. This is what Kwame Anthony Appiah seems to do, relying on some unexpressed anti-essentialist, nominalist dogma. According to him, the Akan belief in sunsum (the individual spirit, the main bearer of one's personality) is in the end equally unfounded as the Western belief in the mind $(2004,33)$. This is a form of skepticism that cannot be carried through: we would have to deny that our knowledge reflects in any way the structure of reality. Our conceptual knowledge may be always tentative and fragmentary (as Blondel holds), but it also represents something real; we can gain nothing by pushing it to drown itself in the flux of life (or atoms), which is itself a product of our thought and imagination.

I believe it would be helpful - for the dialogue - if philosophers recognized the need of a common ground outside of philosophy; or, to put it more aptly, if they realized they are standing on it already. This ground, I would like to say, cannot be reduced to some specific kind of "background knowledge", or to things that seem self-evident to people sharing a particular "life-world", "habitus", or Gadamerian "prejudices". It underlies all that. Only if we believe in the possibility to understand each other as human beings, questions about the translatability of conceptual schemes or narratives can arise.

\section{THE PECULIARITIES OF THE AFRICAN PHILOSOPHICAL PERSPECTIVE}

As an academic discipline with its own goals and methods, African philosophy came into existence when the era of colonization ended. African intellectuals, especially those who were trained in the West, felt the need to take stock of the riches inherent in African cultures, past and present, which they had been taught to neglect or even despise. In the early novels of the Ghanaian writer Ayi Kwei Armah we meet such intellectuals who are at home neither in the West nor in Africa. One of these novels is, tellingly, titled Fragments. Armah was taken to task by the well-known Nigerian writer Chinua Achebe (1975, 39 ff.) for spreading a kind of despair that ordinary Africans were - mercifully - not ready for. In his later novels, Armah evoked an idealized precolonial past, starkly contrasting with what he saw as a materialistic, soulless and predatory Western way of life. 
Many of the founders of (modern) African philosophy lived in the field of tension evoked by Armah. Some were tempted to prove their worth by emulating Western examples, and thus, by their very definition of philosophy, to spurn the wisdom that has been cultivated on the soil of African life for ages. Others devoted themselves to "excavating" traditional wisdom, by collecting proverbs, epics and myths, or interviewing sages, and presented their findings as a ready-made alternative philosophy, fully-equipped to face the philosophies of the West or East. The shortcomings of both approaches soon became a point of discussion. Initially there was very little agreement on what African philosophy should look like. After decades of polarization (among different schools, universalists and traditionalists, professional philosophers and "excavators of philosophical sagacity", Afro-deconstructionists and Afroconstructionists, to mention just a few epithets), now many accept that African philosophy, properly so called, must be critically engaged with African traditions, and explicate values and ideas that Africans adhere to up to today. There are still disputes going on between those who believe African philosophy is just in the making, and those who think it is already there, only waiting to be put into writing.

Even if they were intent on proving that African "sagacity" and philosophy could hold their own in a confrontation with Western or Eastern philosophies, most African philosophers initially aimed at boosting the self-confidence of their fellow Africans, or helping them overcome a sense of inferiority inculcated by colonialists. But there has been a change. Some now confidently address the world at large. Here we can think of Achille Mbembe (e.g., 2000). Drawing on the historical experience of Africans, he denounces developments like privatization, individualization and globalization. In Mbembe's view, the present-day world-wide "power elite" (to borrow a term from the sociologist C. Wright Mills) has the same mentality as colonizers had in Africa; and therefore the fate of oppressed, disenfranchised or enslaved Africans can serve as a warning for the future. (By the way, a similar view was expressed earlier by Armah; one of his characters in the novel Why Are We So Blest? observes, thinking about Americans: "Why should I be so unhappy at this perception: that centuries of purposeful destruction should produce new generations of children born to destroy effortlessly, naturally, easier than they breathe?")

\section{THE OBSTACLES PREVENTING A FRUITFUL EXCHANGE OF VIEWS}

Now, with many, I believe that it would be a good thing if intellectuals in other parts of the world paid attention to views propounded by African thinkers - both views which directly challenge Western attitudes, and those which simply represent the wisdom cultivated in African traditions.

But the cross-cultural dialogue seems to be hampered by a number of factors. (One sign of this is that major international journals devoted to comparative philosophy carry few, if any, articles by Africans or on Africa; those writing on African philosophy mostly have to rely on niche publications.) Some of the obstacles are present in the minds of participants, others are hardly ever mentioned, perhaps being "too large to be 
seen". I will attempt to shed light on some of them, keeping in mind the observations made above on the relation between philosophy and the "unreflected life" - that is, the myopia easily induced by excessive intellectualism. At the same time, I think it is important to recognize the conditions of a shared humanity, which allow us to speak of wisdom or philosophy in the first place, and not to sacrifice them on the altar of a respect for diversity.

What kind of obstacles do I have in mind? Let me present an indicative list (I am not pretending it is exhaustive).

\section{a) The scarcity of written traditional sources}

This obstacle I mention only for the sake of completeness; it has been discussed from the outset. African philosophy, taken in a broad sense, suffers from neglect by Western philosophers, because these tend to think only authoritative or "canonical" texts are worth studying and commenting on. Therefore, traditions dependent on oral transmission are at a disadvantage. Kwame Gyekye has stressed the fact that thought is always the product of an individual mind (1995, $24 \mathrm{ff}$.). But somehow it matters, according to the rules of the "philosophical game", whether the author of a text can be identified or not. By now, of course, there are many books by African philosophers; but many of them present traditional ideas, with a view to either defending or criticizing them. I believe, however, that the lack of a fixed "traditional" corpus which can serve as a starting point for commentary and criticism doesn't fully account for the asymmetry in the discussions between African and Western philosophers.

\section{b) Divergent views on the role and function of philosophy}

African philosophy departed from Western models by attempting to demonstrate the philosophical fruitfulness of African traditions. The attitude African philosophers took towards their cultural environment was very unlike that taken by the Greek founders of Western philosophy. They wanted to reconnect with a given life and way of being, whereas the Greek philosophers distanced themselves from their traditions, in order to gain a critical perspective that wasn't accessible to the "unreflecting mind" - they wanted to sift episteme (truth) from doxa (uncritically-held views). We could say that African philosophy started as a love of the wisdom that was already there; while for the followers of Socrates philosophy was a love of the intellectual powers which allow a transcending of the given and received. This doesn't mean that African philosophers depreciated critical faculties. They insisted that myths and sayings were the product of conscious reflection, for example; but they also stressed the fact that this reflection was tied to the felt responsibility to contribute to a rich social life.

The attitudes of African philosophers towards the "traditional" past were far from uniform or unambiguous, however. From the beginning, the doubt was raised whether, under the heading of "tradition", philosophers (and anthropologists) weren't studying ideas and practices that had been imposed from the outside, or had been transmogrified by the colonizers. There was no uncontaminated tradition, according to some; which 
meant that, in their view, the elements of a truly African philosophy had to be reconstructed. This has led to (in my view) rather questionable attempts to minimize the congruence between African and Western views. Some, like Okot p'Bitek (1979), went as far as to say that all metaphysical ideas referring to a separate, unobservable dimension of reality were the product of Western (mostly religious) indoctrination and this view is still being defended, by D.A. Masolo (2004), among others. Over against the Western "dualistic" view, an African life-world is posited; though it includes all kinds of spirits, it is a self-contained world, in which human concerns and material things are not contrasted with something "higher". This view has been challenged by Emefie Ikenga Metuh; according to him, it was rather the resistance to Western ideas that led (some) Africans to abandon their metaphysics: if the Europeans claimed possession of the only true God, and accused the Africans of worshiping only spirits, they would demonstratively turn to the spirits, and abandon the cult of God (1981, 164). (See also Mohammed Majeed 2013, who criticizes Kwasi Wiredu's contention that Akan conceptions of the person do not go beyond the "quasi-physical".)

Some, like Paulin Hountondji and Peter Bodunrin, and also Wiredu, were not intent on rediscovering an untainted, indigenous African philosophy; they advocated a new approach, which would be properly philosophical instead of descriptive. Wiredu (1976) maintained that much of what was presented as African philosophy was in fact "folk philosophy", and could only be fruitfully compared to uncritically-held views among folk strata in other parts of the world. Even if this criticism may apply to the "ethnophilosophical" approach instanced by Placide Tempels's Bantu Philosophy (the adjective was coined by Marcien Towa [1973] and meant to be pejorative), I believe he conceded too much. It is doubtful whether any philosophy can develop without the support of "naive" views - and Gyekye has given good reasons for supposing it can't (1995, 25). Edwin Etieyibo (2018), Jonathan Chimakonam (2018b) and I. A. Menkiti (2004), among others, have also pointed to the fact that philosophical reasoning is always rooted in historical traditions, or, according to an expression of the latter, in the thought of "the village"; the same point has been made by some Western philosophers, like Hans-Georg Gadamer (1965). A big question here is, whether Western critical and objectivist views also developed under the pressure of an attitude to life that was adopted uncritically. (My answer would be "yes"; see below.)

\section{c) Ontological incommensurability}

I think it is fair to say that the great majority of African philosophers question or oppose the Western "disenchanted" worldview. They do not dismiss, out of hand, the possible existence of all kinds of forces or beings that, in the language of the early disenchanters, should be labelled as "occult", and which they therefore refused to admit in their rational explanations of the universe (deities, spirits, ancestors, and powers allowing the exercise of sorcery, witchcraft and divination; some Westerners would place God in the same category). Western philosophers boast of a tradition that started, with the Ionians, by questioning "naive" views. In this tradition, Occam's razor was applied long before it had a name. Even in the heyday of metaphysics, "higher principles" were 
only admitted if they were deemed necessary for explaining the nature and existence of beings in general. This logic eventually led to the discarding of God, in Laplace's model, because the "hypothesis" of a first mover or a source of being no longer seemed necessary. In the foreshortened view of many Westerners today, the success of Western ways of thinking and acting is due to a desire to explain everything in terms of natural laws. The development of modern science is seen as the result of the courage to let facts speak for themselves, and to let them contradict "intuitive", anthropomorphic conceptions of reality. Post-Enlightenment thought is praised for allowing us to control the natural world in unprecedented ways. Of course, it is precisely this desire for control that African thinkers like Mbembe condemn as a sign of an exploitative, destructive and inhuman attitude to life. Latour, as we have seen, has pointed out that the Western, "modern" self-image was largely the product of self-deception.

Some African philosophers try to avoid a clash between worldviews by describing the African one in very general terms - by saying it implies a logic transcending opposites, or by focusing on the principles of African ethics (the interdependency of human beings, the directedness towards a fulfilling community life, etc.). But even they, when they let their guard down, often let some ontological notions creep in that may bewilder Westerners (at least, those not acquainted with African life). Some, like Gyekye (e.g. 1995, p. 201 ff.) and Martin Odei Ajei (2014) contend that the vindication of the African cultural perspective(s) ultimately rests on proofs establishing the reality of paranormal phenomena. (How this statement can be reconciled with Gyekye's claim that language determines our view of the world, is a brain-teaser.)

Now, I am not one of those Westerners who would categorically dismiss the possibility of non-physical influences. But, as I have often told my African friends, I believe that at least 95 percent of the stories about preternatural occurrings (the dead coming back to life, the effectiveness of magical methods, etc.) are... how to put it delicately?... the product of the imagination. Some stories about strange happenings are simply too good not to be retold. But there is something else. In the traditional "economy", we could say, the institutions of divination, magic, and even witchcraft, are "too big to fail". Criticizing them would amount to invalidating the traditional "solution to the problem of life", which is based on the assumption that everything must go well as long as everyone obeys the prescriptions of tradition. These prescriptions therefore need an infallible foundation. No matter how ambiguous or conflicting the diagnoses of problems pronounced by individual diviners may be; it is imperative to maintain the belief that at least some of them get it right.

Of course, we should also ask which tenets of Western thought are deemed "too big to fail", as the abandoning of them would undermine the physicalistic paradigm, which in turn buttresses the freedom cherished by the bourgeois to do whatever they like (see Abspoel 2017). Some Westerners think that any proof of, say, telepathy, would destabilize their whole conception of reality, and would invalidate their faith in common sense. Some defenders of the African worldview think it would validate traditional beliefs, along with their idea of common sense. What may easily be lost from view in this scuffle, is that the kind of common sense on the basis of which people usually give meaning to their lives may not be tied to the one or the other philosophical conception 
of reality, and may, so to say, happily remain oblivious to such questions.

Interestingly, we don't need to subscribe to any "strange" definition of reality to understand the way the protagonists of African folk tales get into and out of their predicaments. Problems may be defined by referring to miraculous powers of people or animals. But it is not the mastery of esoteric knowledge and fixed routines (like those employed by the diviner) that provide solutions. Special powers never substitute for good sense. It is shrewdness, or even cunning, that wins the day, or, if used unwisely, backfires. The moral is often that it pays to take the advice of other, wiser people. The hero of one story, who unaccountably has been struck with blindness and impotence, frequents traditional healers. They "continued to tell their lies and robbed him of his money. But Alatishe thought: the man who refuses to buy lies will never buy a truth." But his money runs out, and in the end, it is not a healer or diviner that helps him solve his problems; it is his senior wife, who devises of a way to reconcile, by trickery, the conflicting demands of two birds that offer to cure one of his ailments (Gbadamosi 1968, 17).

Yes, as Blondel points out, we may need to believe in some kind of transcendence in order to have the sense that our spontaneous intuitions and ideas cohere, and to be open to a "more complete truth" $(1893,375)$; but this belief strengthens the faith in our normal cognitive faculties and basic common-sense notions. The belief in this kind of transcendence is reinforced by religious traditions. They invite people to recognize their dependence on invisible beings; but they also teach that the most important of these are, so to say, interested in safeguarding the harmonious functioning of the cosmos and society. Therefore, we cannot equate religion with a belief in extraordinary psychic powers. Usually, such powers are not needed to approach the invisible beings invoked in religious ritual; they are certainly not needed to appreciate the kind of "goods" they are implored to deliver.

A belief in exceptional powers of cognition, supposedly conferred by gods or spirits, may be attractive for several reasons. "Seers" may help account for seemingly fortuitous happenings, and may suggest courses of remedial action where instrumental solutions are unavailable. But whether such powers are real or not, there is always a price to be paid for expecting too much from them. There's a thin line between mysteries that attract our attention because we feel a greater receptiveness to them can make our life richer, and mysteries that may undermine our very ability to give meaning to life. The danger may be averted to some extent, by attributing exceptional powers to specific functionaries (diviners, mediums, sacred kings, etc.), and by assigning to them the task to restore or maintain the normal order of life. But we may still come to believe in a blinding light which makes the little light which allows us to make sense of our lives look insignificant. (And the much-maligned Christians would say we need a divine intervention to save us from this danger - that is, to keep faith in our humanity.)

The way traditional beliefs in an "occult economy" immunize themselves against falsification is another problem. Every kind of misfortune is usually explained by pointing to actions that must have disturbed the proper "cosmic order"; that is, to acts of malevolent human beings or spirits, and often, at the same time, to transgressions of the victims that must have deprived them of supernatural protection. Or else, adversity 
is attributed to a neglect of religious duties. No amount of evidence can break this logic (which, by the way, is not specifically African). If views of life containing such beliefs are defended, or presented as alternatives to the "disenchanted" view embraced by modern Westerners, the latter tend not only to object to them on ontological, but also on moral grounds - as they may easily lead to the blaming of victims. Skirting around such issues is not a solution: critics may be encouraged to reject the "strange" cultural perspective as a whole. Clearly, there is no easy way out; by removing all traces of belief in invisible powers, one would render the portrait of African life and thought unrecognizable.

The belief in paranormal powers is also real enough; still, I would say too much is being made of them, when it is suggested the whole African worldview rests on it. Once more it is worthwhile to take note of the contrasting case of African works of literature, which suffer much less from any ontological incommensurability, even if "occult" beings or powers figure in them. It clearly matters whether the reader is invited to look at a strange environment from the perspective of acting human beings, whose motives and responses somehow remain recognizable, or whether the "anatomy" of the alien world is described in abstract terms. Stories invite us to understand the way people deal with situations, and the way they interpret life, without judging. The philosophical elucidation and confrontation of views of life, on the other hand, invites readers to take a critical stance; the way such views function in the lives of others, or in our own lives, may easily escape notice.

\section{d) Pitfalls associated with the hermeneutical approach}

In order to avoid a competition between incompatible ontological models, many African philosophers have taken recourse to a hermeneutical approach, avowedly or unavowedly. (The "conversational school" - see Chimakonam 2020 - can be said to employ a hermeneutical procedure.) This means that they compare conceptual representations of the world without pronouncing on the "objective truth" of either of them. By doing this, they can unwittingly confirm the idea - entrenched in the Western bourgeois mind - that every moral philosophy, religion or Weltanschauung is in the end equally unfounded (see Abspoel 2016, 2017). By making this concession, a dialogue can be maintained between different traditions, and between groups defending or questioning the traditional past (many female intellectuals falling in the latter category), but at a high cost. Ontological relativism is a double-edged sword for those wanting to preserve or change things. Also, dubious hermeneutical assumptions - like the idealistic a priori that the human mind only has access to a reality structured by language or concepts - go unquestioned. And clearly, the sought-for dialogue will exclude many potential participants, like Westerners who view all traditional conceptions of reality with suspicion. Just expounding belief systems without trying to justify them, except by showing their internal, conceptual coherence, may easily have the effect of reinforcing existing prejudices and stereotypes.

Some forms of pressure, ensuing from the situation in which African philosophy developed, seem to have fostered the tendency to reduce traditional ways of life to 
explicit or explicable views. A surprisingly large number of works written by African philosophers focus on "indigenous" views of man, that is, on traditional philosophicalanthropological ideas. These may have been singled out because they were deemed to be the clearest proofs of the presence of philosophical reflection in African life. But often they are made the subject of philosophical scrutiny, as philosophical constructions, without studying the "context" of the life in which they function. And this becomes almost ironical, when it is maintained that African philosophical views betray a respect for the concrete.

This focus on explicit views has been strengthened, I think, by what could be called political considerations. African philosophers wanted to distance themselves from the Western, colonial discourse, and rejected its universalist pretensions, or "logocentrism" (see e.g. Chimakonam 2019, 3). But after tearing this discourse into shreds, and denying the human mind access to any universal "givens", they ended up with fragments which were still made out of language. In a way, they wanted to do what Enlightenment thinkers had done: to break away from a constraining tradition (Chimakonam, in his Ezumezu, praises Francis Bacon for discarding metaphysics $[2019,7])$; but they wanted to do this in order to rehabilitate - at least part of - the African traditional cultural heritage. It is perhaps because they were fighting this twofront war, that they often ended up defending traditional views as an alternative discourse. "Postcolonialism" in theory recognizes or even celebrates particularity and diversity, but it also brings with it a deep distrust of uncritically-held convictions and values.

It is all too understandable that African intellectuals were impressed by the frightening power of stories (like the stories told about them by colonialists, or presenting the Western way of life as absolutely superior). Some of the philosophers among them were inclined to imagine that society was the product of some cybernetic process in which stories or theories were the main determining factors. Thus they came to justify different traditions as the productions of people who freely followed their own reasoning. The question whether people expect more from life than a defensible interpretation of phenomena and experiences, risked getting sidelined. It has often been claimed (see e.g. Barry Hallen and Sodipo 1997, 5; Lott 2011, 26) that African philosophy differs from Western philosophy in being more open to other disciplines, like social and cultural anthropology, sociology and political science. This is not untrue, but I would say African philosophers have often been very selective in what they appropriated from the other sciences, privileging approaches stressing the dependence of the human mind on language, and (though this applies less to women philosophers) neglecting accounts of how traditional ideas have been used to justify inequality, or may have evolved to deal with structural tensions within social systems (see e.g., Douglas 1966).

Now, I do not deny that language molds our reflections and may propose categories that determine the way we deal with specific kinds of objects (or persons). But I do not believe language encapsulates a full-blown culturally-determined attitude to life. If we want to understand culture patterns, we must pay close attention to things that, quite literally, go without saying. For example, the drive to prove oneself in battle (or in some 
other kind of struggle; practicing extreme sports, or sailing single-handedly around the world), which has been an overriding concern for Western elites since immemorial times, doesn't depend on words. It depends on what I call a "subreflexive" motive; and I believe this motive dictates a preference for certain reflexive views instead of being determined by them (see Abspoel 2016, 2017). It certainly strikes me as odd to try to explain such an attitude to life on the basis of some feature of grammar. And I don't see any good reason for assuming that "ordinary" people, who are not in the grips of such overriding concerns, are any more stuck in the ruts of grammar or semantics.

Having said this, I do not deny that the anthropology of the Yoruba, the Igbo, the Luo, and so forth, are equally deserving of philosophical attention as the anthropological models of Plato or Descartes, for example. They are a part of life, but they don't, by themselves, determine all the actions and thoughts of people. It is true, people may often follow the received wisdom, and stick to social norms. They may seem to fly by some autopilot, believing they cannot do better by taking over control. But this is largely an illusion. As Polanyi and Blondel remind us, they wouldn't be able to think anything, or do anything consciously, unless they experienced some support of "tacit knowing" and "direct knowledge". And people who speak the same language, and share the same cultural views, may pursue very different ends.

So I think we should say that the structures that language creates never coincide with the structures that people experience as meaningful in life (see Abspoel, forthcoming). A number of anthropologists - like those who explored the role of the "performative" - have made this point too. An example is Roy Rappaport. He does see language as a grid we impose on reality and which influences our response to it by creating oppositions (between insiders and outsiders, good and bad, permitted and taboo, etc.). But he also points out that language, if left by itself, or rather if left at the mercy of individuals, would only create confusion, discord, "Babel" (1999, 26, 166, 321). The most important "digital" (yes/no) distinctions, separating periods in the lives of communities or individual, or separating acceptable from unacceptable views, are created and supported by means of ritual actions. In order to be accepted as authoritative, meanings and beliefs need to be internalized by the (repeated) participation in rituals, which make them seem evident, and imbue them with a sense of the sacred. Now, Rappaport follows Émile Durkheim (1912) in thinking the sacred is just a societal production, needed for social cohesion. It is necessary as a functional illusion; but the light it provides overrides our critical faculties and therefore cannot serve as a criterion for anything. I think he would have done well to take note of Blondel's criticism of the Durkheimian view; it is not really cogent to think that social facts can mold human aspirations without appealing to (and letting themselves be conditioned by) some disposition or desire rooted in the individual (see Blondel 1906b). Meanwhile, I believe Rappaport is right in emphasizing that in order to have faith in our thinking, we need to have faith in a host of other things that cannot be thought, let alone be replaced by thoughts.

The point I want to make is quite simple. In accounts of African life, found in stories, novels, and ethnographic literature, we find a life that is fed by many springs, and which has many "dimensions" - it is composed of instrumental actions, reflections, 
affections, desires, all kinds of joys, even mystical experiences. I would think it is part of the philosopher's job to try to do justice to the nature, the conditions, and interconnectedness of all these things. In order to do this, he or she must use language. But one should always be wary of the temptation to pretend that the same power that allows one to conjure up an image of life must be responsible for creating what is being imagined. In other words, one should face the (difficult) task of trying to say something about how, and to what extent, our understanding of the connections between many different kinds of things corresponds to the connections given in reality. It is tempting to embrace a model which will decide for us which phenomena we should save and which we should "send walking". But then, we'll have to cope with the fact that in real life we often decide otherwise.

Of course, African philosophers have every right to thematize the pressures they experience, and the way these impinge on their thoughts. But sometimes I wonder if such pressures aren't receiving a more eloquent expression in the works of novelists (we can think again of Armah, but also of Chinua Achebe and many others), who show them affecting real people. African philosophers are acutely aware, more than most of their Western colleagues, of what Chimamanda Ngozi Adichie has called "The danger of a single story" (2009). But many of them seem to have a preference for "stories" that can be understood in abstraction from concrete life, leaving one to wonder in what sense exactly they are about life. The constructivist or hermeneutical - basically idealistic - assumption that we make sense of life by imposing on it the logic of stories (or "schemes", see e.g., Bruner 1990), often obscures the fact that we need the experiences provided by life as much to make sense of stories as the other way around.

\section{e) Misconceptions about the role of philosophical and scientific rationality in the West}

Those engaged in the dialogue - both Africans and Westerners - tend to think that scientific rationality plays a much larger role in Western life than it actually does. Maurice Blondel, Ludwig Wittgenstein, Pierre Bourdieu, Claude Levi-Strauss, Michael Polanyi (who coined the term "tacit knowing"), Michel de Certeau, and Bruno Latour ("We have never been moderns"), have pointed out, each in their own way, that in the West "pre-scientific" ways of thinking are more than just survivals in the anthropological sense. Westerners, like people in other societies, couldn't live in a recognizably human way unless they often rely on forms of common sense which they cannot defend in theoretical terms. Some Western thinkers have pretended that they could offer "rational" recipes which could take over the function of common sense. And many think this fancy has been realized. As not only Westerners, but also Africans are prone to embrace this misconception, a potentially valuable point of contact is missed. Western and traditional African views of life are often opposed, and seen as separated by a Great Divide, or grand partage (Latour 1983, 1991). This split seems far less absolute if we focus on the kinds of thinking or knowing human beings actually rely on in ordinary life. If we realize we all depend on ontological intuitions we cannot relate to an explicit view of life, we can find a possible common ground, and will remember that the African's 
life-world, too, is composed of much more than elements that can be represented in cosmological or mythical models. (As suggested above, folk tales can function as a foil to mythology.)

\section{f) Vestiges of ethnocentric, racist and colonial attitudes}

I have maintained elsewhere that it is a psychological necessity for Westerners to believe that their recipes for creating wealth, equality, and well-being are the best the world has ever seen (Abspoel 2016). Even if their application happens to have very negative - e.g., ecological or social - consequences, they like to believe that Western rationality offers the best remedy. Philosophers are by no means immune to this syndrome, which has been nurtured over the centuries. They can try to be respectful, but this doesn't necessarily mean they are really open to the others' point of view, or are willing to admit that the principles of some good or essential things may elude their grasp. Of course, many African philosophers are acutely aware of a Western sense of superiority. But often they reduce it to intellectual prejudices (Léon Sobel Diagne mentions those of Hegel, Lévy-Bruhl and Heidegger [2004]). In my view, this syndrome is "powered" by sub-reflexive motives - like a will to believe that individual passion or thinking power must suffice to find a complete solution to "the problem of life", to use Blondel's term. The traditional conditions of human experience, and of all forms of rationality, are easily lost from view, and seldom considered seriously. Thus, the belief in a Great Divide is reinforced, as well as the tendency to disparage what is to be found on the other side of it. Here, by the way, it doesn't help that plans to modernize societies in a distinctively African way have largely come to nothing. Few shining examples, therefore, can be cited to demonstrate what can be gained, in modern life, by giving precedence to African precepts. The democratic temper of many African traditions is robbed of opportunities to express itself. This situation is partly due to relentless economic and political pressure exerted from the outside, which was capitalized upon by local elites. Increasing individualism and economization have turned life into a grim struggle for many millions of Africans. Westerners with a taste for cheap wins can indulge themselves (once again). There is no easy fix, obviously, but I believe it is important to try to get to a clear and recognizable diagnosis of the ailment, and to refrain from accusing all "sufferers" of deliberate ill-will.

\section{THE HEART OF THE MATTER}

I have tried to list some factors that, in my view, impede a constructive dialogue between African and Western philosophers. It has not been my intention to prescribe or proscribe anything. Perhaps my exposition suggests that it is mainly the African philosophers who should change their tack. For good measure, let me point out that I believe that, in the current climate, the onus is on them, and unfairly so. If they present African interpretations of the world, they may seem in the eyes of Westerners to come from a strange planet. They will have to justify the fact that they do not draw the line between folk philosophy and "real philosophy" the way their Western colleagues do. 
And it is up to them to try to convince the latter that the kind of views they make the object of scrutiny are not the only sources of meaning people (including themselves) rely on. As I said, I believe they could do themselves a service by stressing the fact that, also in Africa, explicable views do not determine the whole of life, and that, therefore, African life is less strange than it seems when one takes myths or ontological models as a starting point.

To some African philosophers - those stressing the particularity of African views of life - the criticism applies that the anthropologist E.E. Evans-Pritchard long ago levelled against Lucien Lévy-Bruhl. If it were true, Evans-Pritchard said, that "primitive thought" differs altogether from Western thought, as Lévy-Bruhl maintained, "we would scarcely be able to communicate with primitives [this term was then still being freely employed], even to learn their languages. The single fact that we can do so shows that Lévy-Bruhl was making too strong a contrast between the primitive and the civilized" $(1981,127)$. And he says, "It is not so much a question of primitive versus civilized mentality as the relation between two types of thought to each other in any society, whether primitive or civilized, a problem of levels of thought and experience" (131). Here, Evans-Pritchard contrasts associations of a "mystical" kind, which he believes are aroused in ritual situations, with the kind of knowledge people rely on in "practical affairs, which they conduct in an empirical manner" (128).

In my view, there are more than two "levels of thought and experience". A metaphor might help here. Our knowledge of reality - taken in the widest possible sense - is like light broken by various prisms. One of these prisms produces discursive or speculative thought (relating to many subjects). Another furnishes us with rules that govern our behavior in traditional settings, which appear self-evident, but which can only partially be traced back to explicit views. In our spontaneous interaction with other people we rely on a kind of tacit knowing which provides a light of its own. The world of natural phenomena (including human bodies) evokes all kinds of intuitions and associations, often more or less spontaneously falling into a pattern of correspondences and contrasts (edible-inedible, harmless-dangerous, attractive-repulsive, etc.). And then there is the light which allows us to adapt instrumental actions to the structures and workings of "empirical reality". This list is only meant to be suggestive; some might want to add the "light" of love and war, of ritual and narrative and art, or other things. Clearly, some of these prisms are shaped by particular cultural and historical forces; their shape may even distinguish one social group from another within the same society; others are much less variable. From a reflexive point of view, it is difficult to understand how we somehow manage to combine the light provided by these different prisms. But the real complexity of life is even much greater. Each sphere of life (and these spheres are also variable social productions), like the economic, the religious, the political sphere, or the sphere of family life, is characterized by special kinds of reflection, special intuitions, even special ways of treating concrete objects (or bodies). The same holds for different stages of life, which are sometimes clearly separated. And then, what we think or perceive by virtue of these different "kinds of light" depends to a large extent on what we want to do; and our aims may vary from a desire to acquit ourselves of traditional obligations to a passionate desire to impose our will on a world imagined to 
be refractory. Such attitudes to life, determining the actual actions and thoughts of people, collectively or individually, are themselves factors shaping both the "structure" of reality and the way it appears to actors. Given all these baffling complexities, how are we able to understand other people at all? But somehow, as Evans-Pritchard says, we at least do so to a certain extent, or else we wouldn't be able to communicate; and we are able to communicate, even with people from other cultures, about many things that are relevant to us.

Now, I don't intend to abuse my metaphor, by asking where the light is coming from that is refracted, in different ways, by these various prisms. We only see things in the broken light; we cannot turn around to see the prisms themselves, let alone the source of light hidden behind them. And there is no good reason for supposing (like Platonist metaphysicians do) that the source of the light contains in itself all the intelligibility of what we can see by it. At the same time, we cannot suppress the feeling that, however distorted our view may be (or the views we attribute to others), these prisms are capable of revealing aspects of one reality. That is, we feel that, at least normally, associations imposed by our cultural habitus or individual passions do not constrain our experience or thinking to the point that they have nothing to do with reality. I think Blondel was right in suggesting that we switch between different perspectives in order to do justice to a reality that we cannot directly perceive as a whole (or, as Polanyi would put it, can "attend to focally"). But reality, viewed as something independent of us, is never the only integrating factor. A way of life can only exist and keep existing (except for some time under a despotic regime) if it offers to a significant number of people experiences which they find fulfilling, and if it encourages them to have expectations of life. The meaningfulness of life, I would say, is not something projected by a special prism; it is rather a sense or a state of being more or less contented, happy, and hopeful, which is produced in some sort of black box which processes many different kinds of experience.

I don't think I'm stretching my metaphor too far, if I point to the temptation, that especially philosophers are vulnerable to, to think that one of these prisms does not refract light coming from somewhere else, but is actually the source of the light in which we see ourselves, reality, and life. This may be called the temptation of "foundationalism" (see Rorty 1979). A common form of it is the tendency to think that we can understand reality by reducing it to physical processes, and human motives by reducing them to pragmatic concerns. Another is the tendency to view the whole of our experience as mediated by "symbolic structures", "cultural categories", or language. In reality, I believe, we cannot get away from the belief that the truth has something to do with a light which is diffusely reflected in our general experience, and in what we may call (with some reservations) "common sense". We always invoke its authority, even when we focus on the patterns projected by our chosen prisms. And that is why, as Blondel has remarked, we can never actually stick to any intellectualistic conception of reality: in order to think an idealistic view, for example, we need to smuggle in realistic notions, and vice versa (1906a). In order to have any conception of reality, we must believe in a reality that transcends our representations of it.

Once we recognize this, questions concerning the "office" of philosophy loom 
large. Are philosophers supposed just to reflect on reflections - that is, on the patterns produced by the prisms of discursivity or language? But then, which? Those giving shape to religious views, those guiding pragmatic exploits, those structuring social relations...? Or should they try to understand the whole tangle of human motives and ways of thinking? Philosophical traditions often decide these matters, and they decide differently in different cultures.

The interesting thing about comparative or cross-cultural philosophy as a discipline, is that it makes it hard to evade these questions. How does philosophy relate to culture? Can it relate to truth at the same time? And if we believe it can, can it do so without being supported by modes of knowing that cannot be converted into conceptual knowledge? Are cultural perspectives mutually exclusive, or do they complement each other? But if they're all relative; what are they relative to? How and where are we to drive a wedge between the real and illusions induced by wishful thinking, false ideas about causal connections, etc.? Philosophers can ask such questions; this doesn't mean they can answer them all. Western philosophers standing in the Enlightenment tradition often feel they cannot afford to admit their inability to answer them. They stick to a way of thinking which originated in an arms race with religious thinkers. They either believe modern science allows us to distinguish fact from fiction, or they believe (in idealist vein) that we cannot penetrate the veil of concepts or language that separates us from "reality in itself". They are ready to pay the price of having to declare that all cultural meanings are to a large extent illusionary or arbitrary. The attitude African philosophers take towards religion is different: they may reject dogmatism and Western metaphysics, but usually do not reject the, basically religious, notions that are constitutive of traditional life-worlds. So they bring back questions which Western (secular) philosophers feel have been dealt with satisfactorily.

Africans who reflect on the relation between philosophy and culture, will often be faced with the belief of their Western colleagues that Western intellectual culture is not really a culture. In other words, many Western philosophers think they are not dependent on cultural ways of thinking and categorizations, the way the "others" are. Latour, I think, has described the syndrome well. The African philosophers, on their part, often think that Western views are "too rational", or rather, intellectualistic, and therefore fail to do justice to important aspects of life or reality. Their unwillingness to accept what they feel to be constraining categories and ways of thought partly explains their problem to make themselves heard by their colleagues in the West. But I feel they compound their problem by associating the "African perspective" too closely with patterns produced by specific cultural "prisms", and especially by exaggerating the role of language.

Let me try to give an example. In many African cultures it is believed that human beings participate, through some rather mysterious faculty (I can't think of a better word), in a life which embraces the whole universe, and which is supposed to flow from the supreme being. We find this belief expressed in the Akan concepts of okra and honhom (Gyekye, 1995, 88), the Igbo concept of chi (Metuh, $68 \mathrm{ff}$.), the Luo concept of chuny (Masolo 2004, 100), the Oromo concept of ayana (Bartels, $112 \mathrm{ff}$.) - and this is a random sample that could easily be expanded. In old-fashioned metaphysical terms, 
these concepts differ mainly in the degree to which something emanating from the supreme being is supposed to be contracted in the individual (sometimes seen as independent of particular properties - a "breath of life" -, in which case other parts of the person are usually identified, sometimes as individualized, but comprising the whole of the person, or his or her "soul"). But is it really appropriate to describe this (supposed) participation in something transcending the realm of the concrete as just a part of the person, as many African philosophers do? True, it concerns something which is considered to be separable from the body or other "parts" of the person (at death). But at the same time we should say: for someone who believes "it" really exists, it can never be just available as an object of thought - something one can focus on and define -; it will, so to say, be also "behind thought" (even more than any conceptions of reality that we, according to Polanyi, might "attend from"). After all, we would be dealing with a condition of our capacity to experience and think anything. This means, to invoke my metaphor again, that something that is supposed to reflect or refract a transcendent light, is represented as refracted by the prism of conceptual thought; and the problem is that the conceptual gain is hardly ever offset against a possible loss of intelligibility. I would say that it is the reluctance to think in metaphysical terms that is - at least partly - responsible for the fact that attention is often diverted from basic philosophical issues. When treated as ideas or parts of systems of thought, traditional ontological notions hinder the reflection on the conditions of any kind of philosophical thinking. And once one reifies the most internal sources of intelligibility, their relation to other supposedly intelligent "beings" (spirits, ancestors, God, etc.) can only be specified by having recourse to a symbolic or psychological logic. Something, I would say, is bound to get lost in the process.

Attempts to resist reification of what is being signified by traditional ontological concepts, by insisting they are built out of language, make matters worse. African philosophers may think that by adopting a constructivist of hermeneutical view, and staying away from metaphysics, they make differences seem less absolute; but they will discover their Western counterparts, often unconsciously, apply very definite ontological criteria (which seem self-evident to them). The problems of incommensurability or untranslatability often become unsurmountable as a result. Most Western philosophers, it seems, are only ready to talk in their language about issues that can be made to seem relevant using their language. The conditions of all thought and conscious action that (to invoke Polanyi's phrase) cannot be said, are hardly ever thematized. I think a real dialogue can only begin once this is being recognized. To return to my metaphor one last time: I don't think this requires a radical turning around, a facing of the light - an exchanging of shadows for the sun, as in Plato's allegory of the cave. Philosophers need not become mystics, or follow the later Husserl in trying to distinguish some transcendent light allowing us to see our "life-world" as a whole (1970). But there is a negative criterion we can apply, once we realize that the many different ways in which we manage to grasp something of reality depend on each other. People who think they can explain how everything coheres by invoking one or a few principles, often cannot explain how they manage to think such a thing, or even how they are able to conceive of anything like a truth. Also, we can take heart from the 
achievements of literary writers (or the anonymous authors of folk tales), who are somehow able to show how people in practice manage to combine the light refracted by different "prisms", without losing the sense that they are living their own lives or the sense that they share one world with others.

\section{CONCLUDING REMARKS}

My aim has been to take a step back, and try to see what is going on in a field of discussion, realizing it is a field of human action as well. I have not tried to privilege any particular kind of factors, such as those that can be expressed in well-worn philosophical terms. Neither have I chosen to privilege any other viewpoint, like that of the anthropologist or the sociologist of knowledge. In order to combat prejudices standing in the way of a real discussion, it doesn't suffice to identify them, and show them for what they are. It is important to understand how they came about, how they affect our way of thinking, and above all, how they keep us from understanding ourselves.

Comparative philosophy can contribute both to the problem and to its solution. It contributes to the problem, if it shirks from recognizing the conditions of all kinds of human wisdom, regardless of their "substance", and with that, the conditions of any real dialogue. It can work towards a solution, if it inquires into the way different reflexive views (such as theories or myths) find support in reality, or human experience, without considering any of them to be the last word, and without pretending that the real can be defined or grasped in the same way as such views. Only by applying this "method" we can stop ourselves from being lured toward mirages of epistemic certainty (of a foundationalist or constructivist type). If we want our intellectual journey to end in a world we share with others, we need to have faith in familiar landmarks that any human being can recognize. Some may fear that this assumption would cripple our critical faculties; but if this were the case (as Blondel has pointed out) we wouldn't have been able to develop and use them in the first place. Hermeneuticians seem to say something similar - except that they assume that people from different backgrounds share less than they think. We would only understand others insofar as their and our interpretations tally; and we may end up understanding only our own projections. I would say we always share more than we think, and in practice always assume we do. One thing we ought to remember is this: the other we see through a philosophical lens is never the same as the other we meet; and once we realize this, we have reason to say, abusing Rimbaud's words, "Je est un autre."

\section{ACKNOWLEDGEMENTS}

The author would like to thank Herman Westerink, Angela Roothaan, Geert Koefoed, Paul van Tongeren, Hans Altena, and the referees enlisted by Comparative Philosophy for their encouragement and useful comments. 


\section{REFERENCES}

Abspoel, Peter (2016), Zingeving in het Westen: Traditie, strijdersethos en christendom [Sources of Meaning in the West: Tradition, the Warrior Ethos, and Christianity] (Nijmegen: Vantilt).

Abspoel, Peter (2017), "In praise of foolish conviviality: Some thoughts on the unthinkable connection between tradition, spontaneity and ethics", International Journal of Philosophy and Theology 78.3: 234-257. <https://doi.org/10.1080 /21692327.2017.1302813>

Abspoel, Peter (2018), "Tradition as a key to the Christian faith", in International Journal of Philosophy and Theology 79.5: 470-492. < https://doi.org/10.1080 /21692327.2017.1389654>

Abspoel, Peter (forthcoming 2021), Stiefkind van de rede: Essays over de voorwaarden van menselijkheid [Reason's Stepchild: Essays on the Conditions of Being Human] (Eindhoven, Uitgeverij Damon).

Achebe, Chinua (1975), Morning Yet on Creation Day (New York: Anchor Press/Doubleday).

Adichie, Chimamanda Ngozi (2009), The Danger of a Single Story (TEDGlobal).

Ajei, Martin Odei (2014), The Paranormal: An inquiry into some features of an African metaphysics and epistemology (Hamburg: Missionshilfe Verlag).

Appiah, K. Anthony (2004), "Akan and Euro-American Concepts of the Person", in Lee M. Brown (ed.), African Philosophy: New and Traditional Perspectives (Oxford: Oxford University Press), 21-34.

Armah, Ayi Kwei (1968), The Beautiful Ones Are Not Yet Born (Boston: Houghton Mifflin).

Armah, Ayi Kwei (1970), Fragments (Boston: Houghton Mifflin).

Armah, Ayi Kwei (1972), Why Are We So Blest? (New York, Doubleday).

Armah, Ayi Kwei (1973), Two Thousand Seasons (Nairobi: East African Publishing House).

Bernstein, Richard J. (1991), "Incommensurability and Otherness Revisited", in Eliot Deutsch (ed.), Culture and Modernity: East-West Philosophic Perspectives (Honolulu: University of Hawaii Press), 85-103

Bartels, Lambert (1983), Oromo Religion: Myths and Rites of the Western Oromo - An Attempt to Understand (Berlin: Dietrich Reimer Verlag).

Blondel, Maurice (1973 [1893]), L'Action (1893) (Paris: Presses Universitaires de France).

Blondel, Maurice (1898), “L'Illusion idéaliste”, in Euvres complètes, Tome II, 195216.

Blondel, Maurice (1903), "Principe élémentaire d'une logique de la vie morale", in Euvres complètes, Tome II, 365-389

Blondel, Maurice (1906a), "Le point de départ de la recherche philosophique", in Euvres complètes, Tome II, 527-569. 
Blondel, Maurice (1906b), "Lettre a la Société française de philosophie, concernant le rapport de E. Durkheim, 'Détermination du fait moral' ", in Euvres complètes, Tome II, 571-578.

Blondel, Maurice (1934a/b), La pensée, 2 parts (Paris: Librairie Félix Alcan).

Blondel, Maurice (1936, 1937), L'Action, 2 parts (Paris: Librairie Félix Alcan).

Blondel, Maurice (1976), Addition to the entry "Tradition", in André Lalande, Vocabulaire technique et critique de la philosophie (12 ${ }^{\text {th }}$ edition), 1140-1141 (Paris: Presses Universitaires de France).

Blondel, Maurice (1997), Euvres complètes, Tome II (Paris: Presses Universitaires de France).

Bodunrin, Peter (1981), "The Question of African Philosophy", in Philosophy 56: 161179 (London: The Royal Institute of Philosophy).

Bourdieu, Pierre, and Jean-Claude Passeron (1970), La reproduction: Éléments pour une théorie du système d'enseignement (Paris: Les éditions de minuit).

Bourdieu, Pierre (1979), La distinction: Critique sociale du jugement (Paris: Les éditions de minuit).

Bourdieu, Pierre (1980), Le sens pratique (Paris: Les éditions de minuit).

Bruner, Jerome (1990), Acts of Meaning (Cambridge [MA], Harvard University Press). Certeau, Michel de (1980), L'invention du quotidien, I: Arts de faire (Paris: Gallimard). Chimakonam, Jonathan O. (2018a), "Why the 'Politics' against African Philosophy should be Discontinued", Dialogue: Canadian Philosophical Review 57.2: 277-301.

Chimakonam, Jonathan O. (2018b), \& Edwin E. Etieyibo (eds), Ka Osi So Onye: African Philosophy in the Postmodern Era (Wilmington [NC]: Vernon Press).

Chimakonam, Jonathan O. (2019), Ezumezu: A System of Logic for African Philosophy and Studies (Cham [Switzerland]: Springer).

Chimakonam, Jonathan O. (2020), "History of African Philosophy", Internet Encyclopedia of Philosophy (consulted April 2020). <https://iep.utm.edu/afric-hi/>

Davidson, Donald (1980), “Thought and Talk", in Samuel Guttenplan (ed.), Mind and Language (London: Routledge \& Kegan Paul), 7-23.

Davidson, Donald (1982), "On the Very Idea of a Conceptual Scheme", in Jack Meiland and Michael Krausz (eds), Relativism: Cognitive and Moral (Notre Dame [IN]: Notre Dame University Press), 66-80.

Diagne, Léon Sobel (2004), Le problème de la philosophie africaine (Dakar: PRF).

Douglas, Mary (1966), Purity and Danger, An Analysis of Concepts of Pollution and Taboo (London: Routledge \& Kegan Paul).

Durkheim, Émile (1912), Les formes élementaires de la vie religieuse (Paris: Presses Universitaires de France).

Etieyibo, Edwin E. (ed.) (2018), Method, Substance, and the Future of African Philosophy (New York: Springer).

Evans-Pritchard, E.E. (1981), A History of Anthropological Thought (London: Faber and Faber).

Gadamer, Hans-Georg (1965), Wahrheit und Methode: Grundzüge einer philosophischen Hermeneutik, 2. Auflage (Tübingen: J.C.B. Mohr). 
Gadamer, Hans-Georg (1976), Kleine Schriften I: Philosophie, Hermeneutik (Tübingen: J.C.B. Mohr).

Gbadamosi, Bakare \& Ulli Beier (1968), Not Even God is Ripe Enough (London: Heinemann).

Gbadegesin, Segun (2004), "An Outline of a Theory of Destiny", in Lee M. Brown (ed.), African Philosophy: New and Traditional Perspectives (Oxford: Oxford University Press), 51-68.

Gyekye, Kwame (1995), An Essay on African Philosophical Thought: The Akan Conceptual Scheme, revised edition (Philadelphia: Temple University Press).

Hallen, Barry, and J. Olubi Sodipo (1997), Knowledge, Belief, and Witchcraft: Analytic Experiments in African Philosophy (Stanford, CA: Stanford University Press).

Hountondji, Paulin J. (1963), African Philosophy: Myth and Reality (Bloomington [IN]: Indiana University Press).

Husserl, Edmund (1970), The Crisis of European Sciences and Transcendental Philosophy: An Introduction to Phenomenological Philosophy (Evanston, IL: Northwestern University Press).

Kunene, Mazisi (1982), The Ancestors \& the Sacred Mountain (London: Heinemann).

Latour, Bruno (1983), Comment redistribuer le grand partage?, in Revue de synthèse, III $\mathrm{S} . \mathrm{N}^{\mathrm{o}} 110$.

Latour, Bruno (1991), Nous n'avons jamais été modernes: Essai d'anthropologie symétrique (Paris: Éditions La Découverte). English translation by Catherine Porter, 1993, We Have Never Been Modern (Cambridge [MA]: Harvard University Press).

Latour, Bruno (2012), Enquête sur les modes d'existence: Une anthropologie des modernes (Paris: La Découverte).

Lévi-Bruhl, Lucien (1910), Les fonctions mentales dans les sociétés inférieures (Paris: Presses Universitaires de France).

Levinas, Emmanuel, (1990 [1961]), Totalité et infini: Essai sur l'exteriorité (Paris: Librairie Générale Française).

Lévi-Strauss, Claude (1962), La pensée sauvage (Paris: Librairie Plon).

Lott, Tommy L. (2011), "Comparative Aspects of Africana Philosophy and the Continental-Analytic Divide", Comparative Philosophy 2.1: 25-37. <https:// scholarworks.sjsu.edu/cgi/viewcontent.cgi?article $=1088 \&$ context $=$ comparativephi losophy>

MacIntyre, Alasdair (1990), Three Rival Versions of Moral Enquiry: Encyclopaedia, Genealogy and Tradition (London: Bloomsbury Academic).

MacIntyre, Alasdair (1991), "Incommensurability, Truth, And the Conversation Between Confucians and Aristotelians About the Virtues", in Eliot Deutsch (ed.), Culture and Modernity: East-West Philosophic Perspectives (Honolu: University of Hawaii Press), 104-122.

Majeed, Mohammed (2013), "A Critique of the Concept of Quasi-Physicalism in Akan Philosophy", African Studies Quarterly 14.1 \& 2: 23-33.

Masolo, D.A. (2004), "The Concept of the Person in Luo Modes of Thought", in Lee M. Brown (ed.), African Philosophy: New and Traditional Perspectives (Oxford: Oxford University Press), 84-104. 
Mbembe, Achille (2000), De la postcolonie: Essay sur l'imagination politique dans l'Afrique contemporaine, seconde edition (Paris: Éditions Karthala).

Mbembe, Achille (2013), Critique de la raison nègre (Paris: Éditions La Découverte). Mbembe, Achille (2018), Politiques de l'inimitié (Paris: Éditions La Découverte).

Menkiti, I.A. (2004), "Physical and Metaphysical Understanding: Nature, Agency, and Causation in African Traditional Thought", in Lee M. Brown (ed.), African Philosophy: New and Traditional Perspectives (Oxford: Oxford University Press), 107-135.

Metuh, Emefie Ikenga (1981), God \& Man in African Religion: A Case Study of the Igbo of Nigeria (London: Geoffrey Chapman).

Moody-Adams, Michele M. (1997), Fieldwork in Familiar Places: Morality, Culture, \& Philosophy (Cambridge, MA: Harvard University Press).

Nussbaum, Martha C. (1993), "Non-Relative Virtues: An Aristotelian Approach", in Martha C. Nussbaum and Amartya Sen (eds), The Quality of Life (Oxford: Clarendon Press).

p'Bitek, Okot (1979), African Religions in Western Scholarship (Nairobi: Kenya Literature Bureau).

Polanyi, Michael (1946), Science, Faith and Society (Chicago: The University of Chicago Press).

Polanyi, Michael (1958), Personal Knowledge: Towards a Post-Critical Philosophy (London: Routledge \& Kegan Paul).

Polanyi, Michael (1956), The Study of Man (London: Routledge \& Kegan Paul).

Polanyi, Michael (1966), The Tacit Dimension (New York: Doubleday).

Rappaport, Roy A. (1999), Ritual and Religion in the Making of Humanity (Cambridge: Cambridge University Press).

Rorty, Richard (1979), Philosophy and the Mirror of Nature (Princeton: Princeton University Press).

Rorty, Richard (1989), Contingency, irony, and solidarity (Cambridge: Cambridge University Press).

Tempels, Placide (1945), La philosophie bantoue (B.P. 1259, Elisabethville [Belgian Congo]).

Towa, Marcien (1973), Philosophy and Contemporary Africa: Dimensions of the Black intellectual experience (Washington D.C.: Black Orpheus Press).

Wiredu, Kwasi (1976), "How not to compare African traditional thought with Western thought", in Transition 1.2 (Bloomington [IN]: Indiana University Press), 320-327.

Wiredu, Kwasi (1980), Philosophy and an African Culture (Cambridge: Cambridge University Press).

Wittgenstein, Ludwig (1958), Philosophical Investigations (Oxford: Blackwell).

Wong, David (1989), "Three Kinds of Incommensurability", in Michael Krausz (ed.), Relativism: Interpretation and Confrontation (Notre Dame, IN: University of Notre Dame Press), 140-158.

Wong, David (2009), Natural Moralities: A Defense of Pluralistic Relativism (New York: Oxford University Press).

Wright Mills, C. (1956), The Power Elite (Oxford: Oxford University Press). 